\title{
Evaluation of Mango (Mangifera indica L.) Cultivars on the Basis of Quality Characters of Fruit under Faizabad Condition
}

\author{
Archit Singh* and Sanjay Pathak \\ Department of Fruit Science, College of Horticulture \& Forestry, Narendra Dev University of \\ Agriculture and Technology, Faizabad-224 229 (U.P.), India \\ *Corresponding author
}

\section{A B S T R A C T}

\begin{tabular}{|l|}
\hline K e y w o r d s \\
Mango, Cultivars, \\
Peel, Pulp, Fruit, \\
Sugar
\end{tabular}

The observations were recorded on physico-chemical characters of mango fruits. The maximum fruit length was recorded in Samarbehist Chausa, whereas the highest fruit breadth was recorded in Bombay Green. The maximum fruit weight, fruit volume, pulp weight and pulp: stone ratio and minimum stone weight were recorded in Banarasi Langra. Better quality fruits with respect to highest total soluble solids, reducing sugars and lowest acidity percentage were recorded in samarbahist Chausa. The highest ascorbic acid and total sugars were recorded in Banarasi Langra, while, the maximum non-reducing sugar was recorded in Rataul. Overall it can be concluded on the basis of quality of fruits, Bombay Green and Gulab Khas were observed as early variety whereas Dashehari, Banarasi Langra and Langra Kukori as mid-season variety and Samabahist Chausa as a late variety to be found best under Faizabad condition. These varieties possess good quality characters and superior overall the varieties under this study.

\section{Introduction}

Mango (Mangifera indica L.) is also known as "King of fruits" and "National fruit of India". It belongs to the family Anacardiaceae. The mango is indigenous to north-east India and north Myanmar in the foot-hills of the Himalayas, and is said to have originated in the Indo-Burma region. Mango is one of the most preferred, widely distributed, and broadly grown tropical fruit in the world. Mangoes are gaining commercial importance in all over the world and assume a leading position in among the fruits. Although a tropical fruit, the mango grows equally well under semi-tropcal conditions. Due to the long history of cultivation in this subcontinent, about a thousand cultivars of mango are known to exist in India. The fruit quality is attributed to its physical characteristics, especially the color of skin and fruit's shape and size. The fruit skin is smooth, thick and commonly yellow or greenish in color when matured. The quality attributes such as colour, shape, size and flavour should be maintained in newly evolved varieties so that India can increase its presence in the international market (Thulasiram et al., 2016).

All the parts of its plant have various uses in India. Both ripe and unripe mangoes are used extensively by food processing industry to 
prepare a wide variety of products such as syrup, jam, squash, juice, cereal flakes and toffee etc., from ripe mango. Pickles, chutney, slices, amchur, candy, jam, jelly preserve, squash etc., from unripe mango (Meena et al., 2005).

Mangoes are rich source of vitamin- $A$ and also contains of vitamin-B, vitamin-C, calcium, iron, potassium in fair amount. Mangoes have more carotenoids than most of other fruits. Carotenoids help to reduce the risk of cancer and heart diseases. Chemical composition of mango differs with the variety and stage of maturity. A comprehensive report has been made on the chemical composition after analysis of more than 25 varieties of mango (Anonymous, 1966). According to this report, chemical constituents in mango are moisture (73.0-86.7\%), carbohydrate (11.6$24.3 \%)$, protein $(0.3-1.0 \%)$, fat $(0.1-0.8 \%)$, minerals $(0.3-0.7 \%)$ per cent, vitamin A (65025940 I.U./100g), vitamin C (3-83 mg/100g), calcium $(0.01 \%)$, phosphorus $(0.02 \%)$ and iron $(4.5 \mathrm{mg} / 100 \mathrm{~g})$.

In Uttar Pradesh, the popular commercial cultivars are grown viz. Bombay Green, Dashehari, Fajri, Langra, Safeda Lucknow, Chausa, Ratual, Amarpalli and Malihabadi. These cultivars are gaining popularity due to attractive colour, pleasant flavor, taste, sugars, less fibers and pulpiness. Through these cultivars are grown all over the country but Uttar Pradesh is the leading producer of these cultivars.

In general, the cultivars are location-specific and the commercial cultivars of one region do not do so well when grown in other areas. Uttar Pradesh is divided into 9 agro- climatic zones in which Faizabad comes under eastern plain zone, therefore, there is need to evaluate the recommend variety which can be successfully grown as well as prove to be profitable for this zone.

\section{Materials and Methods}

The experiment was carried out at Main Experimental Station, Department of Horticulture, Narendra Deva University of Agriculture \& Technology, Kumarganj, Faizabad (U.P.) during the year 2015-16. Geographically it is situated at $26^{0}-47^{0} \mathrm{~N}$ latitude, $82.12^{0} \mathrm{E}$ longitude of 113 meter above from mean sea level. This site is located in typical saline-alkaline belt of indigenous plains of eastern Uttar Pradesh. This region is characterized by sub-humid and sub-tropical climate. Approximately, $1200 \mathrm{~mm}$ precipitation occurs, out of which about 85 per cent is concentrated from mid-June to end of September.

The experiment on mango was conducted in Randomized Block Design (RBD) with twelve treatments were Each variety was replicated thrice and spaced at a distance of $10 \times 10 \mathrm{~m}$. Plants were of uniform in age (22 years) and received same cultural practices during the course of investigation. The Selected varieties were Dashehari, Banarasi Langra, Langra Kukori, Bombay Green, Nisar Pasand, Gulab Khas, Himsagar, Lucknow Safeda, Rataul, Gaurjeet, Samarbahist Chausa and Zardalu and used as treatments $\mathrm{T}_{1}, \mathrm{~T}_{2}, \mathrm{~T}_{3}, \mathrm{~T}_{4}, \mathrm{~T}_{5}, \mathrm{~T}_{6}$, $\mathrm{T}_{7}, \mathrm{~T}_{8}, \mathrm{~T}_{9}, \mathrm{~T}_{10}, \mathrm{~T}_{11}$ and $\mathrm{T}_{12}$ respectively.

The observations were recorded on physicochemical characters of fruit as length of fruit $(\mathrm{cm})$, breadth of fruit $(\mathrm{cm})$, fruit weight $(\mathrm{g})$, volume of fruit $\left(\mathrm{cm}^{3}\right)$, pulp weight $(\mathrm{g})$, stone weight $(\mathrm{g})$, pulp/stone ratio, total soluble solids (\%), acidity (\%), ascorbic acid content $(\mathrm{mg} / 100 \mathrm{~g})$, reducing sugar $(\%)$, non-reducing sugar $(\%)$ and total sugar $(\%)$.

\section{Results and Discussion}

The results obtained from the present investigation as well as relevant discussion have been presented under following heads: 


\section{Physical characters of fruit}

A careful investigation of the data showed that there was significant variation in fruit length and fruit breadth among the cultivars. The maximum fruit length was recorded in Samarbahist Chausa $(9.37 \mathrm{~cm})$ which was at par with the Dashehari $(9.17 \mathrm{~cm})$ followed by Zardalu $(9.10 \mathrm{~cm})$. Whereas, the minimum fruit length was recorded in Gaurjeet $(5.63 \mathrm{~cm})$ (Table 1).

The maximum fruit breadth was noted in Bombay Green $(6.57 \mathrm{~cm})$ which was at par with the Banarasi Langra $(6.20 \mathrm{~cm})$ followed by Himsagar $(6.13 \mathrm{~cm})$. However, the minimum fruit breadth was noted in Gaurjeet $(4.47 \mathrm{~cm})$. These results are in agreement with reports of Hoda et al., (2002) and Yadav et al., (2010). Although the size of fruit is a varietal character, it may be some extent influenced by the total number of fruit born on the tree, source sink relation and other factors.

Significant variation in a fruit weight and volume of fruit were recorded among different cultivars of mango. The highest fruit weight recorded in Banarasi Langra (186.67g) followed by Langra Kukori (178.67g) and Samarbahist Chausa (177.33g). While, the lowest fruit weight were noted in Gaurjeet $(96 \mathrm{~g})$. The maximum volume of fruit recorded in Banarasi Langra $\left(179 \mathrm{~cm}^{3}\right)$ followed by Langra Kukori $\left(171.17 \mathrm{~cm}^{3}\right)$ and Samarbahist Chausa $\left(168 \mathrm{~cm}^{3}\right)$. While, the lowest fruit weight were noted in Gaurjeet $\left(87.33 \mathrm{~cm}^{3}\right)$. Which were close those reported by Kumar $e t$ al., (2000); Bakshi et al., (2013) and Kaur et al., (2014). The variation amongst the varieties as regards to fruit weight and volume of fruit might be due to genetic variability, inherent characters, climatic adoptability and management practices in particular region. This might prove an important diagnostic character for selection of varieties for local conditions.
The statistical analysis of data indicated that significant variations in pulp weight, stone weight and pulp: stone ratio existed among different cultivars of mango. The maximum pulp weight was recorded in Banarasi Langra (135.50g) followed by Samarbahist Chausa $(124.80 \mathrm{~g})$ and Zardalu (121.20g). Whereas, the lowest value was recorded in Gaurjeet $(63.67 \mathrm{~g})$. Among the cultivars evaluated, the minimum stone weight was recorded in Gaurjeet (13.5g) followed by Banarasi Langra (20.33g) and Rataul (21.08g). However, the maximum value was recorded in Dashehari $(28.36 \mathrm{~g})$.

Cultivar Banarasi Langra (6.66) showed highest pulp: stone ratio followed by Langra Kukori (4.91) and Bombay Green (4.66). The minimum pulp: stone ratio was noticed in Lucknow Safeda (2.82). These results are partially supported the findings of Dhillon et al., (2004); Siddique et al., (2004); Kundu et al., (2010); and Jilani et al., (2014). The variation amongst the varieties as regards to pulp weight, stone weight and pulp: stone ratio might be due to the difference in agro-climatic conditions and the genotypes under study.

\section{Chemical characters of fruit}

Significant variation in TSS, acidity and ascorbic acid were recorded among different cultivars of mango. The TSS content was recorded highest in Samarbahist Chausa (20.78 Brix $^{0}$ ) followed by Banarasi Langra (19.98 Brix $\left.{ }^{0}\right)$ and Langra Kukori (19.56 Brix $\left.^{0}\right)$. While, the lowest TSS was recorded in Rataul (16.19 Brix $\left.^{0}\right)$. Which were close those reported by Yadav et al., (2010) and Singh et al., (2013). The maximum acidity was recorded in Rataul $(0.49 \%)$ followed by Lucknow Safeda $(0.43 \%)$ and Gaurjeet $(0.37 \%)$. Whereas, the minimum acidity was recorded in Samarbahist Chausa (0.24\%). The similar trends are also reported by Kumar et al., (2005) and Sengupta et al., (2006) (Table 2). 
Table.1 Data regarding physical attributes of different mango cultivars

\begin{tabular}{|l|c|c|c|c|c|c|c|}
\hline Treatments & $\begin{array}{c}\text { Fruit } \\
\text { length } \\
(\mathbf{c m})\end{array}$ & $\begin{array}{c}\text { Fruit } \\
\text { Width } \\
(\mathbf{c m})\end{array}$ & $\begin{array}{c}\text { Fruit } \\
\text { weight } \\
(\mathbf{c m})\end{array}$ & $\begin{array}{c}\text { Volume } \\
\text { of fruit } \\
\left(\mathbf{c m}^{\mathbf{3}}\right)\end{array}$ & $\begin{array}{c}\text { Pulp } \\
\text { weigh } \\
(\mathbf{g})\end{array}$ & $\begin{array}{c}\text { Stone } \\
\text { weight } \\
(\mathbf{g})\end{array}$ & $\begin{array}{c}\text { Pulp : } \\
\text { stone } \\
\text { ratio }\end{array}$ \\
\hline Dashehari & 9.17 & 5.40 & 169.00 & 161.33 & 114.17 & 28.36 & 4.02 \\
\hline Banarasi Langra & 9.07 & 6.20 & 186.67 & 179.00 & 135.50 & 20.33 & 6.66 \\
\hline Langra Kukori & 8.87 & 6.10 & 178.67 & 171.17 & 118.67 & 24.16 & 4.91 \\
\hline Bombay Green & 8.10 & 6.57 & 176.00 & 167.83 & 115.50 & 24.83 & 4.65 \\
\hline Gulab Khas & 7.20 & 4.77 & 129.83 & 120.17 & 81.50 & 22.17 & 3.68 \\
\hline Nisar Pasand & 7.43 & 5.60 & 147.83 & 139.17 & 92.77 & 25.06 & 3.70 \\
\hline Himsagar & 7.03 & 6.13 & 151.50 & 141.3 & 106.67 & 23.83 & 4.48 \\
\hline Lucknow Safeda & 7.17 & 4.53 & 120.83 & 111.50 & 68.63 & 24.33 & 2.82 \\
\hline Rataul & 7.47 & 5.57 & 146.67 & 137.67 & 86.83 & 21.83 & 3.98 \\
\hline Gaurjeet & 5.63 & 4.47 & 96.00 & 87.33 & 63.67 & 13.50 & 4.72 \\
\hline Samarbahist Chausa & 9.37 & 5.70 & 177.33 & 168.00 & 124.80 & 27.53 & 4.53 \\
\hline Zardalu & 9.10 & 5.43 & 167.33 & 158.83 & 121.20 & 26.33 & 4.60 \\
\hline S.Em. \pm & $\mathbf{0 . 1 3}$ & $\mathbf{0 . 1 3}$ & $\mathbf{3 . 6 1}$ & $\mathbf{3 . 1 0}$ & $\mathbf{2 . 0 5}$ & $\mathbf{1 . 0 6}$ & $\mathbf{0 . 1 0}$ \\
\hline C.D. at 5\% & $\mathbf{0 . 3 9}$ & $\mathbf{0 . 4 0}$ & $\mathbf{1 0 . 6 0}$ & $\mathbf{9 . 1 1}$ & $\mathbf{6 . 0 1}$ & $\mathbf{3 . 1 1}$ & $\mathbf{0 . 2 9}$ \\
\hline
\end{tabular}

Table.2 Data regarding chemical attributes of different mango cultivars

\begin{tabular}{|l|c|c|c|c|c|c|}
\hline Treatments & $\begin{array}{c}\text { TSS } \\
(\%)\end{array}$ & $\begin{array}{c}\text { Acidity } \\
(\%)\end{array}$ & $\begin{array}{c}\text { Ascorbic } \\
\text { acid } \\
(\mathbf{m g} / \mathbf{1 0 0 g})\end{array}$ & $\begin{array}{c}\text { Reducing } \\
\text { sugars } \\
(\%)\end{array}$ & $\begin{array}{c}\text { Non - } \\
\text { reducing } \\
\text { sugar }(\%)\end{array}$ & $\begin{array}{c}\text { Total } \\
\text { sugars } \\
(\%)\end{array}$ \\
\hline Dashehari & 18.28 & 0.29 & 34.98 & 3.01 & 12.04 & 15.05 \\
\hline Banarasi Langra & 19.98 & 0.26 & 74.28 & 3.68 & 11.86 & 15.54 \\
\hline Langra Kukori & 19.56 & 0.27 & 66.31 & 3.53 & 11.68 & 15.21 \\
\hline Bombay Green & 18.73 & 0.31 & 45.97 & 3.17 & 11.95 & 15.12 \\
\hline Gulab Khas & 17.89 & 0.36 & 33.41 & 2.80 & 10.94 & 13.74 \\
\hline Nisar Pasand & 18.68 & 0.34 & 30.16 & 2.79 & 11.30 & 14.09 \\
\hline Himsagar & 18.59 & 0.35 & 22.61 & 2.66 & 12.58 & 15.24 \\
\hline Lucknow Safeda & 17.17 & 0.43 & 31.19 & 2.19 & 12.10 & 14.29 \\
\hline Rataul & 16.19 & 0.49 & 66.84 & 2.10 & 13.08 & 15.18 \\
\hline Gaurjeet & 17.28 & 0.37 & 41.53 & 2.45 & 12.66 & 15.11 \\
\hline Samarbahist Chausa & 20.78 & 0.24 & 26.09 & 3.98 & 11.03 & 15.01 \\
\hline Zardalu & 19.22 & 0.28 & 27.89 & 3.33 & 11.27 & 14.60 \\
\hline S.Em. \pm & $\mathbf{0 . 2 2}$ & $\mathbf{0 . 0 2}$ & $\mathbf{1 . 2 6}$ & $\mathbf{0 . 1 3}$ & $\mathbf{0 . 1 9}$ & $\mathbf{0 . 2 7}$ \\
\hline C.D. at 5\% & $\mathbf{0 . 6 5}$ & $\mathbf{0 . 0 5}$ & $\mathbf{3 . 7 1}$ & $\mathbf{0 . 3 9}$ & $\mathbf{0 . 5 6}$ & $\mathbf{0 . 7 9}$ \\
\hline
\end{tabular}

The ascorbic acid was recorded highest in Banarasi Langra $(74.28 \mathrm{mg} / 100 \mathrm{~g})$ followed by Langra Kukori (66.31 mg/100g) and Rataul (49.30 mg/100g). Whereas, the cultivar Himsagar $(22.61 \mathrm{mg} / 100 \mathrm{~g})$ had lowest ascorbic acid. Similar results were documented by Gautam et al., (2003); Singh et al., (2003) and Dutta et al., (2004). 
However, the higher and lower values for TSS, acidity and ascorbic acid showed inheritance, which is quite helpful in finding the suitable elite types as per requirements. This might prove an important diagnostic character for selection of varieties for local conditions.

The statistical analysis of data clearly indicated that different cultivars had significant variation in reducing sugars, nonreducing sugar and total sugars of fruit.

The maximum reducing sugars was recorded in Samarbahist chausa (3.98\%) which was at par with the Banarasi Langra (3.68\%) followed by Langra Kukori (3.53\%). However, the minimum value was recorded in Rataul (2.10\%).

The highest non-reducing sugar content was estimated in cultivar Rataul (13.08\%) which was statistically at par with the Gaurjeet (12.66\%) followed by Himsagar (12.58\%). Whereas, the minimum value was recorded in Gulab Khas (11.03\%). Among the cultivars evaluated, the maximum total sugars were recorded in Banarasi Langra (15.54\%) which was at par with the Himsagar followed by Langra Kukori (15.24\%) and Bombay Green (115.21\%). While, the minimum value was recorded in Gulab Khas (13.74\%). The present findings are strongly agreed with the results reported by Shivanandam et al., (2008); Naz et al., (2014); Rana et al., (2015). The variation in reducing sugars, nonreducing sugar and total sugars among varieties might be due to variation in genetic variability, inherent characters and climatic adoptability in particular region.

\section{References}

Anonymous, 1966. Mango cultivation. Extn. Bull. 9, IIHR, Bangalore, India.

Bains, K. S. and Dhillon, W. S. 1999. Physico chemical character of different mango
(Magnifera indica L.) cultivar grow under sub mountainous condition of Punjab. Haryana J. Hort. Sci., 28(3\&4): 174-176.

Bakshi, P., Kumar, R., Jasrotia, A. and Sharma, A. 2013. Variability in physico-chemical and sensory attributes of mango genotypes under rainfed conditions of Shivalik Foothills of Himalayas. Asian J. Hort., 8(1): 39-42.

Dhillon, W. S. and Kumar, A. 2004. Some physio-biochemical changes during fruit development in pomegranate. Indian $J$. Hort., 61(3): 219-222.

Dutta, P. 2004. Effect of foliar boron application on panicle growth, fruit retention and physico-chemical characters of mango cultivar Himsagar. Ind. J. Hort., 61(3): 265-266.

Gautam, B., Sarkar, S. K. and Reddy, Y. N. 2003. Effect of post-harvest treatment of shelf life and quality of Banganpalli mango. Ind. J. Hort., 60(2): 135-139.

Hoda, M. N., Singh, S. and Singh, J. 2002. Performance of mango hybrids under Sabour conditions. Ind. J. Hort., 15(2): 27-32.

Jilani, M. S., Bibi, F., Waseem, K and Khan, M. A. 2014. Evaluation of physico-chemical characteristics of mango (Mangifera indica L.) cultivars grown in D. I. Khan. J. Agric. Res., 48(2).

Kaur, M., Bal, J. S., Sharma, L. K. and Bali, S. k. 2014. An evaluation of mango (Mangifera indica L.) germplasm for future breeding programme. African $J$. Agric. Res., 9(20):1530-1538.

Kumar, N. and Jaiswal U. S. 2003. Bearing behaviour of some West and South Indian mangoes. Haryana J. Hort. Sci. 32(3\&4): 154-156.

Kumar, R. 2000. Analysis of fruit weight components in mango. Orissa J. Hort., 28(2): 70-72.

Kumar, R. and Singh, S. 2005. Evaluation of some mango varieties for flowering, fruiting and fruit quality attributes. Orissa J. Hort., 33(11): 56-59.

Majumder, D. A. N., Hassan, L., Rahim, L., and Kabir M. A. 2011. Studies on physio- 
morphology, floral biology and fruit characteristics of mango. J. Bangladesh Agril. Univ., 9(2): 187-199.

Meena, U. S. and Kumar, S. 2005. Glimpses of Post-Harvest Technology. N.V. Publications, New Delhi.

Mitra, S., Kundu, S. and Mitra, S. K. 2001. Evaluation of mango strain of mango grown in West Bengal. Ind. J. Agric. Sci., 71(7): 466-488.

Naz, S., Anjum, M. A., Chohan, S., Akhtar, S. and Siddique, B. 2014. Physico-chemical and sensory profiling of promising mango cultivars grown in peri-urban areas of Multan, Pakistan. Pak. J. Bot., 46(1): 191198.

Pandey, S. N. $19852^{\text {nd }}$ Int. Symp. on mango, India, Abst., No. 2. 16.

Rajan, S., Kumar, R., Yadava, L. P., Sharan, R., Bhal, C. and Verma, J. P. Lu, P. 2013. Variability pattern in mango (Mangifera indica L.) accessions of diverse geographical origins. Acta Hort., 99(2): 341-351.

Rana, R. K., Bharadwaj, S. S. 2015. Evaluation of mango germplasm for growth, yield and fruit quality in the sub-tropical climate under rain fed conditions of Himachal Pradesh. Annals of biology, 31(2):279-283.

Rangana, S. (2010). Handbook of analysis and quality control for fruit and vegetable products. Tata McGraw-Hill Ltd., New Delhi.

Sengupta, S., Munsi, P. S. and Pujari, M. M. 2006. Studies on the performance and prospect of some promising mango hybrids in the Gangetic plains of Eastern Bihar. Orissa J. Horticult., 34(2): 74-77.
Shattir, A. E.; and Abu-Goukh, A. B. A. 2010. Physico-chemical changes during growth and development of papaya fruit. Agriculture and Biology Journal of North America., 1(5): 866-870.

Shivanandam, V. N., Ramachandra, K. V. and Gowda, T. N. V. 2008. Physico-chemical characteristics of some mango (Mangifera indica Linn.) varieties and hybrids. Mysore J. of Agr. Sci., 42(4): 648-651.

Singh, A. 2012. Approximation of fruit weight by using fruit dimensions in mango (Mangifera indica L.). Prog. Hort., 44(1): 47-51.

Singh, J., Singh, R. R., Yadav, G. S. and Singh, U. K. 2004. Studies on correlation and path analysis in mango. Journal of Applied Biology, 14 (2):34-36.

Singh, S. 2003. Evaluation of mango genotypes for their flowering, fruiting and fruit quality attributes. Ann. Agri. Res., 24(2): 234-238.

Singh, T. K., Singh, J and Singh, D. B. 2013. Performance of mango varieties in Kymore platue of Madhya Pradesh. Progressive Horticulture, 45 (2): 268272.

Thulasiram, R., Alagumani, T. and Duraisamy, M. R. 2016. Preferences of quality attributes for mango export: a conjoint analysis approach. Int. Res. J. Agri. Economics and Statistics, 7(1): 42-47.

Yadav, P. K., Chaturvedi, O. P., Yadav, D. K. and Yadav, H. C. 2010. Physico-chemical attributes of promising mango germplasm of Northern Gangetic Plains. Plant Archives, 10(1):407-409.

\section{How to cite this article:}

Archit Singh and Sanjay Pathak. 2018. Evaluation of Mango (Mangifera indica L.) Cultivars on the Basis of Quality Characters of Fruit under Faizabad Condition. Int.J.Curr.Microbiol.App.Sci. 7(09): 1070-1075. doi: https://doi.org/10.20546/ijcmas.2018.709.127 